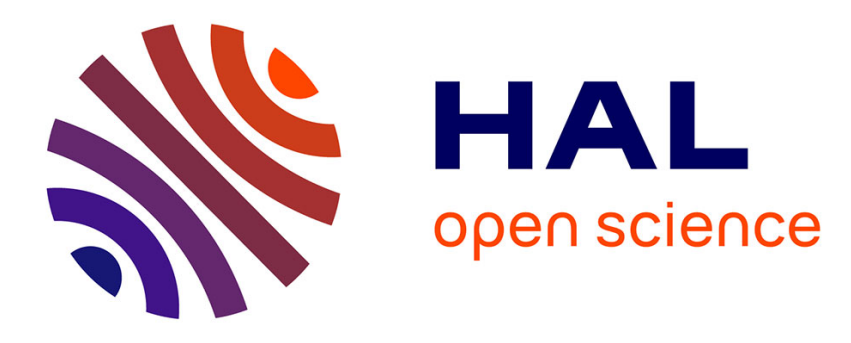

\title{
On the Residential 'Clubbisation' of French Periurban Municipalities
}

\author{
Eric Charmes
}

\section{To cite this version:}

Eric Charmes. On the Residential 'Clubbisation' of French Periurban Municipalities. Urban Studies, 2009, 46 (1), pp.189-212. halshs-00354858

\section{HAL Id: halshs-00354858 \\ https://shs.hal.science/halshs-00354858}

Submitted on 1 Dec 2014

HAL is a multi-disciplinary open access archive for the deposit and dissemination of scientific research documents, whether they are published or not. The documents may come from teaching and research institutions in France or abroad, or from public or private research centers.
L'archive ouverte pluridisciplinaire HAL, est destinée au dépôt et à la diffusion de documents scientifiques de niveau recherche, publiés ou non, émanant des établissements d'enseignement et de recherche français ou étrangers, des laboratoires publics ou privés. 


\section{On the residential "Clubbisation" of the French Periurban Municipalities ${ }^{1}$}

Final draft. Final paper published in 2009, in Urban Studies, vol. 46, n 1, p. 189-212.

In French periurban municipalities, the relationship to the local environment has changed: principles of justice considered legitimate by periurbanites are increasingly less associated to the political sphere and more attached to the economic sphere. Some municipalities (especially those with less than 2000 inhabitants) carry out policies that are increasingly similar to the management of private residential clubs. Thus, regarding territorialisation of periurbanites, the major transformation is less a rise in the prerogatives of the private sector to the detriment of the prerogatives of the public sector, than a change in the philosophical definition of the relationship to residential space. More precisely, the former should be regarded as a symptom of the latter, and not as a cause.

The neologism "clubbisation" is not very elegant, but explains rather well the transformations that have taken place during the last decades in French periurban municipalities. French periurbs approximately correspond to outer suburbs and metropolitan fringes, or to what is more and more often called "exurbs" in the United-States. ${ }^{2}$ Yet, contrary to American exurbs, which in many cases are governed at the county level, French periurbs are always governed by municipalities, that is at the territorial level of the commune. Moreover, periurban communes are sparsely populated, with an average population of around 820 inhabitants.

As it will be demonstrated in the last section of this article (section 5), periurbanites' relationship to those communes has changed: principles of justice considered legitimate are increasingly less associated to the "political sphere" and more attached to the "economic sphere". ${ }^{3}$ As a consequence, the economic concept of club (as it was coined by James Buchanan) has gained an incontestable relevance to analyse periurban political life. Thus, some periurban communes carry out policies that are increasingly similar to the management of residential clubs, and comparable to the management of common interest developments (McKenzie, 2005). This observation is important because it puts into question the

\footnotetext{
${ }^{1}$ I would like to thank the anonymous reviewers for their comments on a first version of this paper. I would also to thank the translator of this article, Christine Humphries. All mistakes are still mine however.

2 The Brookings Intstitution recently proposed a definition of exurbs that is consistant with the French definition of periurbs (see Berube et alii, 2006: 5-6). The similarity is greater if exurbs are defined at the "census tracts" level. See section 2 for a presentation of the criteria used by the French National Statistical Office to classify areas as periurban.

3 This distinction is a classical one among pluralist philosophers. Here we use the analytical tools developed by Michael Walzer in Spheres of Justice (1983). See (Miller \& Walzer, 1995) for a critical appraisal of Michael Walzer's defence of separate spheres of justice.
} 
predominance of the theme of privatisation in debates around residential territorialisation (Jaglin, 2008). Indeed, the evolution of French local governments reveals that regarding territorialisation of periurbanites, the major transformation is less a rise in the prerogatives of the private sector to the detriment of the prerogatives of the public sector, than a change in the philosophical definition of the relationship to residential space. More precisely, the former should be regarded as a symptom of the latter, and not as a cause.

This article also shows that residential clubbisation particularly concerns communes with core built-up area ${ }^{4}$ of under 2,000 inhabitants (which is the case of a large number of periurban communes). In more populated communes, the political sphere remains preponderant and the principles of justice peculiar to this sphere continue to regulate local collective life. This observation suggests that the thematic of "private city" over-emphasizes the ongoing transformations. More research is necessary on this subject, but one can hypothesize that when the population threshold that defines a neighbourhood as being residential is exceeded, i.e., when the scale of a small town is reached, the political sphere remains predominant.

Before getting to these results, we will begin by presenting the economic concept of club, using on the one hand the work of James Buchanan and on the other hand the recent work of Chris Webster (2002; 2003; see also Webster \& Lai, 2003). We will also present Tiebout's model, not only because this model is considered to be the precursor of James Buchanan's work, but also because it considers local jurisdictions as a market of clubs offering various bundles of local collective goods. Indeed, Tiebout's model provides an important framework for this article. The clubbisation of a commune has no real meaning if it is considered in isolation and analyzed solely in terms of the commune's internal transformations. The meaning of clubbisation can only be fully appreciated when it is linked to a system of prices regulating access to the bundles of local collective goods offered by the communes. For this reason, we will analyze in Section 4 the functioning of the periurban residential market. This analysis will suggest that the purchase of a property is often a way of becoming a member of a residential club established around a commune.

In this article, detailed consideration of periurban communes in France is also essential. Their case is indeed unusual. In Section 2, it will be emphasized that these communes not only have important powers, but also that many of them are sparsely populated. For example, Paris metropolitan area (aire urbaine) has 1,584 communes for 11,2 million inhabitants and a large number of these communes, notably in the exurbs, have less than 2,000 inhabitants. Clubbisation or, more precisely, the process of transformation into residential clubs, is a particular concern for these communes.

The original data presented in this article are based on studies that are described in Section 3. These studies were undertaken within a primarily sociological and geographical theoretical framework. The use of economy in this article is both pragmatic and external; the facts confronted in the following pages are given meaning by considering economy as a reservoir of ideas and concepts. It is important to insist on this point because the concept of clubbisation has, in all likelihood, no definite meaning from an economic standpoint. According to the definition of Chris Webster and Lawrence Wai-Chung Lai (2003:

\footnotetext{
4 It means that this threshold does not include the population of hamlets and peripheral groups of houses. However, the population of the latters is usually a small fraction of the population of the core built-up area.
} 
53, 119), the concept of club can be used to analyze the economic functioning of any commune. But what this article shows is not that communes become clubs from an economic standpoint, but that communes enter into a market logic from a political and philosophical standpoint. Consequently, the concept of club becomes appropriate for the commune's sociopolitical analysis (a change which raises questions about its political legitimacy, a point that will be re-considered in the conclusion).

\section{On Club Goods and the Tiebout Model}

The simplistic opposition of private and public goods is insufficient to account for the uses, the property rights and interests that are associated to places. Sociologists use for example the concept of community to define places that are not private (because there are many shared spaces) or public (because they are more or less closed to those that do not belong to the community). For their part, economists have gone beyond the opposition between public and private with a classification system of goods that uses two criteria: the opportunity to exclude others and rivalry with other users. The crossover between these two criteria results in four categories (see Table 1). Two categories are the traditional private and public goods, the third category is club goods and the fourth is common goods. Club goods are not private (because their use can be shared without rivalry), and at the same time, are not public (because their use can be reserved for a particular social group). Common goods are defined as goods from which no user can be excluded, but that are exhausted as they are used (the classical, yet contested 5 , example is of the commons, pasturelands that are open to all).

\begin{tabular}{|c|c|c|}
\hline & \multicolumn{2}{|c|}{ Exclusion } \\
\hline & Easy & Difficult \\
\hline High Rivalry & Private goods & Common goods \\
\hline Low Rivalry & Club goods & Public goods \\
\hline
\end{tabular}

Table 1: Classification of Goods According to the Economic Theory (Ostrom, Gardner \& Walker, 1993: 7)

As in all classification systems, these categories do not take into account the diversity of all possible situations. In particular, the categorisation of some goods can be unclear. Furthermore, categorisation is determined along historical or cultural lines (Webster \& Lai, 2003); some public goods can thus become private or club goods because evolving technology allows, at a modest cost, individualizing usage or detecting those who have not paid their dues. As a case in point, in a frequently quoted article, Ronald

5 See the contribution of Elisabeth Blackmar, titled "the tragedy of property rights discourse", in (Low \& Smith, 2006: 49-80). 
Coase proves that it is even possible to find an institutional arrangement that removes the signal from a lighthouse from the category of public goods (Coase, 1974; and Fischel, 2000 for a recent commentary).

Despite its flaws, the principal advantage of this classification is that it transcends the traditional dichotomous classification of public and private. Within this classification system, the most important factor for a residential road is not whether it is public or private, but whether it can be a club or common good. It is a club good when a gate is placed at its entrance and when the street becomes a playground (a residential street rarely becomes congested with children playing6). It is a common good when parking is in an issue and when owners compete for parking spots (Charmes, 2005: Chapter 3).

Of course, people sharing one or several club goods are members of a club. Economists Todd Sandler and John Tschirhart give the following definition to the concept: "a club is a voluntary group deriving mutual benefits from sharing one or more of the following: production costs, the member's characteristics, or a good characterized by excludable benefits" (1997: 335).

The foundations of the economic theory of clubs and of club goods are based on James Buchanan's work and, more particularly, on his article published in 1965 called: "An Economic Theory of Clubs". In his article, however, James Buchanan is interested in clubs primarily as a way to avoid the intervention of public authorities. At that time, collective goods were believed to be providable and manageable only by public authorities. For orthodox Anglo-Saxon economists, this represented a "problem", because in this school of thought government interventions must remain minimal (for arguments supporting this view see Foldvary, 1994). Yet, with the concept of club it became possible to think of collective use of a good while retaining, through excludability, the possibility of making users pay a price for consuming this good. Establishing a club made it possible to overcome the mandatory supply by the public sector. James Buchanan was very much in line with this way of thinking and it was for this reason that he was above all interested in non-governmental private clubs.

Nevertheless, a club is not at all incompatible with public property or public management. Before the publication of James Buchanan's article, the idea that local jurisdictions can serve as membership devices giving access to a specific bundle of goods had been discussed (Fischel, 2000). In an article published in 1956 that would later become well-known, Charles Tiebout imagined a mechanism to establish a form of market for a particular category of public goods, goods provided by local public governments. Charles Tiebout presented a simple solution for this type of goods: use municipalities (numerous in the United-States) as providers of a specific bundle of local public goods. As long as certain assumptions more or less realistic are met, in particular the existence of free and unconstrained residential mobility ${ }^{7}$, Charles Tiebout demonstrated that people can express their preferences not with their vote but by "walking to a community where the prices (taxes) of the community services are set" (1956: 422). In other words, people can reveal their preferences by moving into a municipality in which the local facilities and tax level meet their expectations. As a result, allocating a market value to local public goods is no longer problematic.

Although Charles Tiebout does not use the word "club" in his 1956 article, it is evident in his model that the bundles of goods proposed by local governments are club goods. Thus, as in James Buchanan's

\footnotetext{
${ }^{6}$ This does not preclude rivalry with other users of the street, especially car drivers.

${ }^{7}$ See (Dowding \& John, 1994) for a detailed discussion of these assumptions.
} 
article, one of Charles Tiebout's principal points of discussion concerns the optimal size of groups benefiting from packages of local public goods 8 .

Yet, Charles Tiebout did not really discuss the related problem of excludability. Unfortunately Charles Tiebout died at the age of 44 , and he did not have the opportunity to refine his model and to study how municipalities could give their inhabitants exclusive access to club goods. It was therefore other researchers who showed that, given control of urban planning and taxing powers, municipalities can regulate access to goods they provide, ensure funding for these goods and, establish their price (see, among others, Oates, 1969; Hamilton, 1975; Fischel, 2000; Webster, 2002):

- Urban planning and land use by-laws allow municipalities to control the supply of buildable land, which in turn allows them first to regulate the number of inhabitants and second to exclude many potential buyers from the outside. In this way, municipalities can prevent the congested use of collective local goods. In the periurbs, regional planning may also help to restrict access to club goods: indeed, distance and green belts may act as devices restricting membership of a local community (London outer suburbs are a case in point).

- The power to charge taxes and fees averts free rider behaviours among those living inside the jurisdiction (which leaves open the problem of free riders living outside the jurisdiction).

- The impact of land use by-laws and of local policies on building values (through "capitalisation") allows action to be taken on the entry fee required to be part of the municipality. Annual dues associated with residency in the municipality can also be set through local taxes. In France, studies on the periurban ring of Rennes have shown that the amount of the entry fee is much more significant than the amount of the annual fee (Guengant, 1992: 104).

Despite this study and a few others (Gilbert \& Guengant, 2002), France has not been used much to test Tiebout's model. Past studies have focused mostly on the United-States. Nevertheless, as presented in this article, French periurban communes are an environment conducive to the formation of a market of local collective goods' bundles.

\section{French Periurban Communes}

Before discussing methodology and the results of case studies, we will describe French local governments. This is particularly important because the actual situation differs from the commonly perceived image of France as a centralised country. If this image was pertinent in the 1960s, it is no longer now. In fact, at the beginning of the 1980s, decentralisation laws considerably expanded the autonomy of local governments. The base level, the commune, was given significant responsibilities, in particular in the domain of land use. Since these changes, a mayor can determine zoning regulations and the type of authorized constructions (collective or individual habitat for example).

Without question, these laws have revitalized democratic life by raising local issues to the policy level. However, all the communes regardless of their size or location were given the same prerogatives. As a

\footnotetext{
${ }^{8}$ See the discussion of the seventh hypothesis on which Charles Tiebout bases his model (1956: 419).
} 
result of the political power of the rural population in France, large urban communes did not benefit, unlike those in Germany for example, from a judicial or administrative autonomy significantly different to that of small rural communes (Wollmann, 2000). A mayor has the same administrative and judicial powers whether his or her commune is small or large, urban or rural. Thus, the difference between these communes is essentially at the political level; a function of the budgets managed and of the number of electorates represented.

The resulting fragmentation of local powers poses serious problems for the planning and governance of large metropolises and, in particular, for the political processing of the interdependencies between urban centres and their periphery. These problems are exacerbated all the more so because French municipalities are so numerous and small. It is the United-States which is most commonly considered to be the country where metropolitan areas are the most fragmented into a multitude of separate governments (Judd \& Swanstrom, 2004: 262). Yet, France can easily vie with the United States. As stated in the introduction, the Paris metropolitan area has 1,584 communes for 11,2 million inhabitants. These communes are also very dissimilar: some communes are very populated, while others are not. For example, Paris is a single commune of 2.1 million inhabitants whereas many communes of the inner suburbs have a population of between 40,000 and 100,000 inhabitants. The political relationships of the latter with the numerous communes of the Paris metropolitan region that have less than 2,000 inhabitants are not simple.

These relationships are even more complicated because these sparsely populated communes are in a distinctive geographical position. Almost all of them are periurban (périurbaines). The French National Statistical Office (INSEE) defines communes as such when the following two conditions are met:

- at least $40 \%$ of the persons in the labour force work outside of their boundaries and in one or more aires urbaines (an aire urbaine, or metropolitan area, is made of one pôle urbain and the periurban ring of communes under its direct influence; pôles urbains are themselves made of continuously built-up urban centers offering at least 5,000 jobs and their periurban rings are defined by the periurban communes surrounding them).

- the built-up areas are always at least 200 metres away from the built-up areas of the pôles urbains (in the cases under study, these pôles urbains are the built-up areas of Paris and Lyon)9

As mentioned in the introduction, the average population of the communes périurbaines is around 820 inhabitants. ${ }^{10}$ The total population of periurbanites adds up to over 12 million, which represents $21 \%$ of the total French population. In France mainland, there are 14,930 periurban communes out of a total of 36,565 communes (of which approximately half are "rural" communes and a little more than 3,000 are "urban"). Most periurban communes were formerly rural and have existed for centuries (communes in their common form appeared during the Revolution of 1789 and were delimited according to the preexisting parishes).

The average population of periurban communes masks the great variation in the actual number of inhabitants. Many periurban communes have several thousand or even ten thousand inhabitants.

\footnotetext{
${ }^{9}$ Like all statistical definitions, this definition has certain drawbacks (Charmes, 2005: 21-22).

10 According to the last national census of the French National Statistical Office (INSEE), in 1999.
} 
These communes are often old market towns that have been absorbed into an expanding metropolis. For all that, a strong majority of the periurban communes (between 70 and $90 \%$, depending on the local situations) still have a population the size of a small village.

As stated above, any municipality, small or big, has sufficient political and administrative means to manage its territory with significant political autonomy. Indeed, as each mayor makes decisions on the development of his or her own territory, many communes resemble small kingdoms. This is the most striking in the case of small periurban communes. Indeed, a well established policy regarding land uses and planning among these smaller communes is to maintain a belt of rural and agricultural land around the built-up area. As the built-up area remains a modest size, it frequently appears as an isolate. When this built-up area is underlined by the relief of a surrounding natural or agricultural land, the visual effect of an "autonomous village" becomes striking. (Pinson \& Thomann, 2002; see also Frame 1).

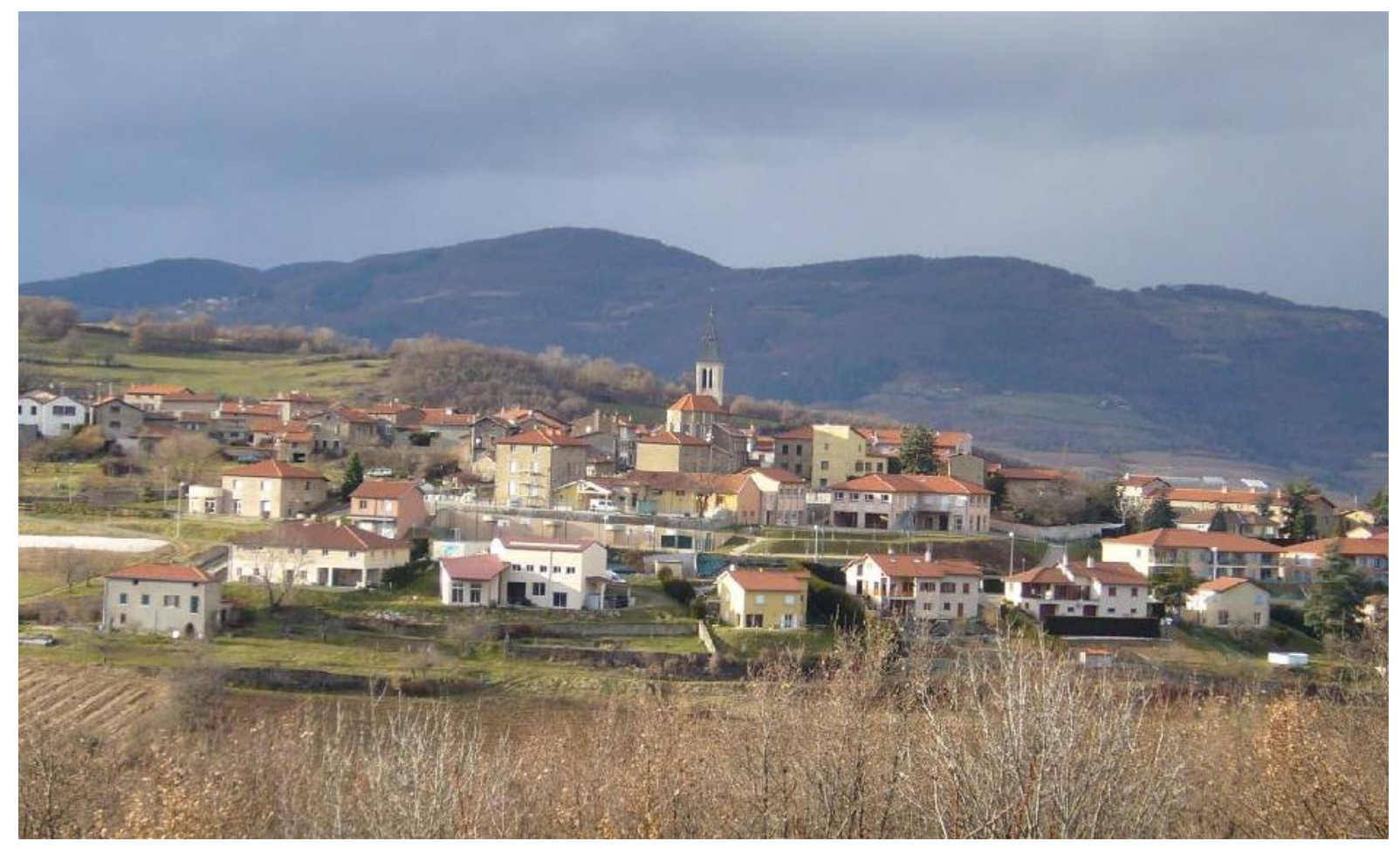

Frame 1: An autonomous looking periurban commune (Lyon's metropolitan area)

Thus, the French periurbs can be described as mosaics where most squares are communes made up of a core village, surrounded by more recent single-family housing developments of a few dozen houses, and finally, surrounded by a belt of natural or agricultural areas. Of course, with such landscape characteristics and with their low population, these communes are predisposed to becoming residential clubs. Residential clubbisation is, in fact, a common process. 


\section{About the Field Work}

This article builds on two qualitative studies of single-family housing developments in the periurban areas of Paris and Lyon. ${ }^{11}$ These urban regions are the two biggest in France with a total population (periurban ring included) of 11.2 and 1.6 million inhabitants each (as these figures indicate, Paris metropolitan area is seven times more populated than France's second largest metropolitan area).

\begin{tabular}{|lc|l|ll|}
\hline Metropolitan area & Population & Nb. of communes & $\begin{array}{l}\text { Nb. of periurban } \\
\text { communes }\end{array}$ & $\begin{array}{l}\text { Avg. pop. of } \\
\text { periurban } \\
\text { communes }\end{array}$ \\
\hline Paris & $11,175,000$ & 1,584 & 1,188 & 1,288 \\
\hline Lyon & $1,648,000$ & 296 & 194 & 1,546 \\
\hline
\end{tabular}

Source: INSEE, 1999 national census

Table 2: Characteristics of the two metropolitan areas studied

The first study conducted fifty or so open-ended interviews with households (Charmes, 2005). The families interviewed were middle-income (these included people employed as middle managers, high school teachers, technicians and employees). A significant number of the people at the head of the household were also retired. The families interviewed generally owned a house erected on a piece of land of 500 to $1000 \mathrm{~m}^{2}$, worth 300000 Euros in 2005 (most of the families interviewed had purchased their house several years prior to the study, at a much lower price). The interviews focused on residential choices, and on relationships to surroundings. The households interviewed were all living in three communes, including Gressy (see Table 4). Complementary interviews with real-estate agents were also conducted in which some of the practices and expectations of periurbanites were further revealed.

This study led to the proposal that certain communes experience a process of residential clubbisation. A second study was therefore initiated to further test this hypothesis. This second study involved qualitative interviews with local councillors and mayors within two groups of approximately 15 communes (Charmes, 2006). One group is of communes located close to the north-eastern limit of the continuously built-up area of Paris, and is made up of two cantons, the canton of Claye-Souilly and the

\footnotetext{
11 These two research projects were financed by the Plan Urbanisme Construction Architecture (French Ministry of Ecology). We thank this institution and its members for their support.
} 
canton of Mitry-Mory ${ }^{12}$ (cantons are administrative districts which, in periurban and rural areas, are generally make up of one small town and its satellite villages). Communes from Mornant's canton, located in the southeast of greater Lyon, make up the second group. A few other communes from the outer fringes of Paris and from the periurban ring of a smaller city (Orléans) have also been studied with the help of two graduate students (Laurent Acelor and Abiola Zofoun).

The characteristics of the population of the two groups of communes studied in the periurban rings of Lyon and Paris are presented in Tables 3 and 4. Like Edmond Préteceille does, these communes can be described as "mixed-income areas" (2006). This social mix is limited, however, as these areas are characterized by the absence of the affluent (mainly found in downtown centres and in posh inner suburbs) and of the poor (mainly found in inner suburbs victimized by deindustrialization). Furthermore, a growing socio-spatial differentiation is observed between the communes.

\section{A Market of Residential Clubs?}

Among the periurban communes very different paths exist in their development. This diversity can be explained at several levels. ${ }^{13}$ At the metropolitan level, a division along large quadrants can be observed; this division mirrors the internal social division of the agglomeration. Thus, if chic neighbourhoods are in the west quadrant of the city centre, the chic suburbs and periurbs will also tend to be in the west. This division has been nullified in this present study because specific quadrants have been studied.

\subsection{Three Sub-Markets}

Inside a given quadrant, the housing market can be subdivided into three sub-markets. These submarkets correspond to three types of communes. The first (type I) includes small communes on the leading edge of periurbanisation. These quasi-rural communes, often of a few hundred inhabitants, still have a significant number of farmers and employees working in the manufacturing of food product (see Tables 3 and 4). They are in the first phase of a strong demographic growth that is essentially driven by the arrival of first time home buyers from the lower middle-classes, many of which are blue-collar

\footnotetext{
12 The commune of Mitry-Mory was not itself included it the study as it is not a periurban commune. It is the "last" commune of Paris continuously built-up area before entering the periurbs. Some other communes like Villeparisis and Courtry were in the same situation.

${ }^{13}$ Regarding the case of Paris metropolitan region, see Baccaïni, 1998; Préteceille, 2003; Berger, 2006
} 
workers or employees..$^{14}$ The presence of these households is due to their poor purchasing power. While having been able to become property owners, they have had to move far away from central zones in order to do so. Because of their type of population, these periurban zones look like "off-the-edge" cities, as described by Edward Soja in his case study of Los Angeles (2000: 259-263; for the French case see Rougé, 2005). The amount of blue-collar households can reach 40 to $50 \%$ (farm workers included).

The second type (type II) includes communes of at least 2,000 inhabitants. With populations such as these, type II communes generally function as centres of services and facilities for smaller communes in the vicinity. This situation is often the legacy of a rural past when villages of a few hundred inhabitants gravitated around a small town, forming a canton. When the latter begins to periurbanise, the villages become type I communes, while the small town becomes type II.

Many of the type II communes have a secondary school (a collège). They attract different types of households. In the town centre, consisting of row houses and small apartment buildings, young couples, old people and low income households are primarily found; whereas in the detached housing estates situated in the perimeter of the centre, more well-off families are found. Beyond these internal differences, the general sociological profile of type II communes reflects their immediate environment. If they are surrounded by type I communes, that is if they are on the leading edge of periurbanisation, then they tend to be populated, on average, by lower middle class households. Nevertheless, the value of the local built heritage and the quality of the landscape (inhabitants greatly appreciate the relief and the presence of vineyards and of fruit trees) can introduce important variations (e.g. Riverie in Table 3).

The third and last type (type III) includes residential communes located in the oldest periurban rings whose populations are usually below 2,000 inhabitants, and above those of type I communes. In a group of 10 communes within one of these rings (a canton for example), between 7 and 9 are type III. Urbanisation has reached maturity in these communes. This maturity manifests itself mainly with urban planning bylaws limiting demographic growth to, at most, one percent per year (and an actual growth rate lower than that). Single-family housing predominates and the commune is almost exclusively dedicated to residential activities. Frequently, besides a city hall, the primary community facility is a local school (a canteen, a small playing field, a gymnasium and a drop-in day-care program are eventually added). As a rule (which like any rule has exceptions), these communes have more affluent households than those of type I. In those quadrants studied, a large part of the population belongs to the intermediary middle-classes (high school teachers, policemen, etc.). In some cases, the share of the upper middle-class households (managers of small companies, university lecturers, engineers, etc.) may reach $40 \%$. Nevertheless, unlike in countries such as the United-States, there are few well-off households. As indicated above, in France the affluent continue to live in old centres or in chic inner suburbs. Furthermore, before belonging to type III, many of these communes belonged to type I. Most households which moved in to the commune at that stage stayed in their house. This explains why bluecollar households still make up a significant portion of these communes. Yet, when the share of bluecollar households reaches $40 \%$ or more, as it is sometimes the case, other explanations must be considered. This is the purpose of the following sub-section.

\footnotetext{
${ }^{14}$ For more details on lower, intermediary and upper middle-classes, see the work of Louis Chauvel (2006)
} 


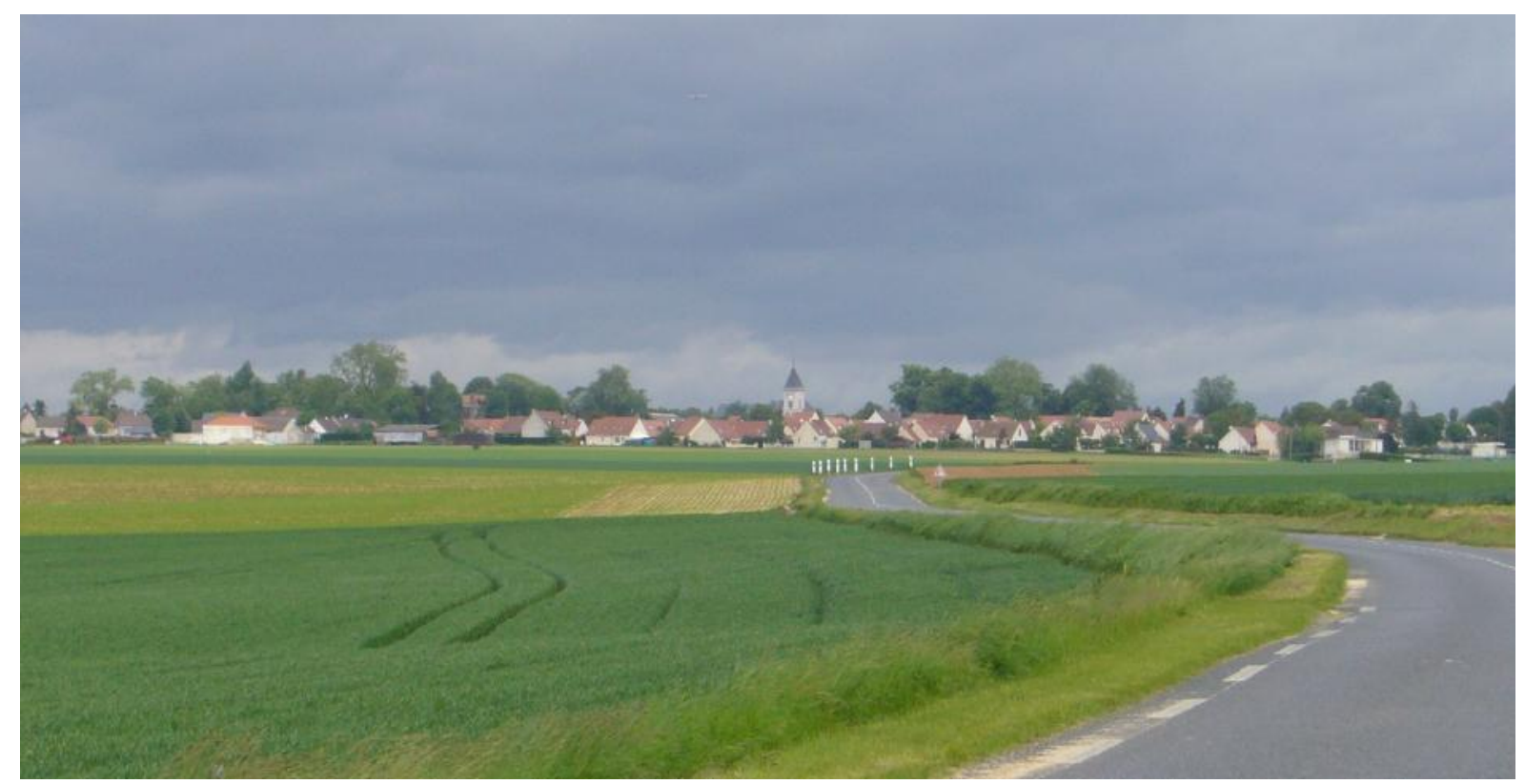

Frame 2: A Type III Commune East of Paris

\subsection{Among Type III Communes: Significant Differences}

Inside a given type, and notably within type III, specific social profiles assert themselves. All type III communes were rural before becoming periurban but, during their progression from rural to periurban, communes follow different paths. It is not always possible to predict the periurban future of a commune by considering its rural past, even if clues exist. For example, a high quality landscape or the presence of old mansions would be considered signs of a future attractiveness to a commune, whereas the presence of a factory would be considered a sign of a lesser attractiveness. The particular identity of a community takes shape progressively, as residential migrations occur. Once started, this process feeds itself. Indeed, as it will be shown in the following sub-section, affluent households attract other affluent households.

The case of two communes north-east of Paris will allow us to measure the possible differences. The two communes, Thieux and Gressy, both have fewer than 1,000 inhabitants and are almost equidistant from the centre of Paris. Moreover, they are only a few minutes away by car from each other. ${ }^{15}$ These two communes were very rural in the 1960s and they both began to periurbanise at that time, but then they followed different paths. The opening of the Charles de Gaulle airport in 1974 changed everything. Thieux was submitted to the nuisances of landings and takeoffs, whereas Gressy remained relatively shielded from the noise of planes. Furthermore, before the opening of Charles de Gaulle airport, when the periurbanisation of the commune began at the end of the 1960s, the Mayor of Gressy wanted to preserve the garden of an old bourgeois mansion, which gave a particularly attractive landscape to his 
commune. Presently, the annual revenue per "fiscal household"16 in Gressy is 34,100€, or 2.25 times the average earning of 15,200€ in Thieux (see Table 4). In Thieux, professionals, managers and entrepreneurs ${ }^{17}$ represent only $2 \%$ of the working population compared to $40 \%$ in Gressy. Conversely, employees and blue-collar workers ${ }^{18}$ represent $60 \%$ of the working population in Thieux compared to $17 \%$ in Gressy. These differences between the populations of the two communes are also found in the flow of migration. Between 1990 and 1999, 7 times more managers and professionals ${ }^{19}$ moved to Gressy than to Thieux (in proportion to the number of people who work that moved into the commune).

\subsection{A Socio-spatial Mosaic of Communes}

The periurban areas are thus becoming a socio-spatial mosaic with large more or less homogenous quadrants and within these latter more or less pronounced nuances. Stark social contrasts exist between type I and type III communes, but as shown above, there can be significant differences among type III communes. This evolution brings the periurbs nearer to the urban centres, with the exception of three differences. The first difference is that social differentiation is confined primarily within the spectrum of the lower to upper middle classes (Préteceille, 2006). The second unique characteristic of the periurban areas is that the gaps in the spatial distribution of the populations are accentuated by the discontinuity of the built-up areas, with agricultural or natural areas sandwiched between the centres of each commune. The socio-spatial mosaic is in large part a mosaic of communes spatially isolated from one another. The third difference is that every one of these population units is endowed with a significant political autonomy despite the fact that many of them have only a few hundred inhabitants (unlike central and inner suburb communes that usually have several tens of thousands, or even several hundreds of thousands of inhabitants).

In that context, according to our interviews, the purchase of a periurban house increasingly includes the purchase of an entry ticket to a communal residential club. Like in any land and house market, a person moving in to a dwelling becomes a "member" of a group of residents characterised by their common enjoyment of a particular living environment. Yet in French periurbs, this living environment is in many cases associated to one commune, whose jurisdictional limits are further underlined by a green belt (Donzelot, 2004; Charmes, 2006). Evidently, this situation is an environment conducive to the formation of a market of communes. Whether this market is Tieboutian is a question that falls outside the scope of our competencies and would undoubtedly be best answered by economists. Notwithstanding, it can be understood that clubbisation occurs within the framework of a market of local collective goods' bundles.

\footnotetext{
${ }^{16} \mathrm{~A}$ "fiscal households" is a set of individuals (usually a family living under the same roof) filling the same form for income tax.

17 That is cadres, professions intellectuelles supérieures and chefs d'entreprises. For definitions of French occupations and socio-occupational categories, see: www.insee.fr/en/nom_def_met/nomenclatures/pcs.htm.

18 That is employés and ouvriers.

19 That is cadres and professions intellectuelles supérieures.
} 


\section{Periurban Communes as Residential Clubs}

In the following pages, the functioning of type III communes will be particularly insisted upon and discussion surrounding the two other types of communes will be limited to helping better explain how type III communes function. It will become apparent that these communes increasingly have certain similarities to residential clubs. Insisting on the dynamic nature of the process will help justify the use of the suffix "-isation" after the term club to form the neologism "clubbisation".

\subsection{A Consumerisation of Relationships to the Commune}

In his seminal article, Charles Tiebout makes residential mobility an essential condition for the functioning of his model: «The act of moving or failing to move is crucial. Moving or failing to move replaces the usual market test of willingness to buy a good and reveals the consumer-voter's demand for public goods. Thus each locality has a revenue and expenditure pattern that reflects the desires of its residents" (1956: 420). Our more sociological approach to periurbanites' relationships to their environment shows the crucial role of mobility in the sociological changes that lead to residential clubbisation.

The relations of periurbanites with their immediate environment are complex and varied, but they are structured by what one of the major transformations of the last decades: the development of a culture of mobility (Urry, 2000; Rémy, 2004; Charmes, 2007b). Urbanites have certainly always been mobile in their everyday life, mobility has even been regarded since the beginning of urban sociology as an integral component of urban life; nevertheless, the effects of this mobility are increasingly perceptible.

These effects are particularly evident in political and civic local commitments. In France, during the 70s, periurbanites were often very involved in municipal politics. They considered their "village" to be a place to implement community projects (Bidou, 1984). This belief has since weakened, particularly with the emergence of a new generation (Brevard, 2003; Jaillet, 2004). ${ }^{20} \mathrm{~A}$ number of factors can explain this change, such as the weakening of communitarian utopias (very strong in the 70s) for the benefit of an individualist hedonism, or the diminishing availability of time in everyday life. Nevertheless, the development of a culture of mobility seems to be an important explanatory factor (Ramadier, 2002).

Here, daily and residential mobilities combine their effects. First, the increase in the number of spaces for daily life and the reduction of time spent at home have furthered the emergence of a division of labour in the relationship to the residential environment. The municipal administration becomes like a provider of services, acting on delegation from inhabitants who no longer have time to take on local issues themselves. Moreover, those local issues are more and more reduced to matters usually dealt with by common interest developments, and periurbanites tend to consider their municipal board like the

20 The observations made by Robert Putnam (2000) are not unrelated to ours. 
board of a common interest development. This phenomenon is particularly obvious in type III communes, since these are the most specialised in residential uses. This specialisation is itself permitted by daily mobility: it is this mobility that allows periurbanites to work and to shop beyond the limits of their communes.

For its part, residential mobility finds resonance with the formation of a market of places and the reinforcement of the hedonist dimension of the relationships to the local environment. The case of an affluent Gressy inhabitant, a man of about 35 years of age, speaks for itself. Questioned on his degree of attachment to his commune, he answered that his present dwelling is only a temporary place. Furthermore, he considers his dwelling and his environment as consumer goods: "I bought the house like I would buy a car; it seems to do for the moment because I have my family, but it is like a car that I would buy because I want to go fast or I want to go slowly". In his assertion of hedonism as a rationale for choosing a place of residence and of the residential mobility as a condition of this choice, the case of this inhabitant of Gressy is rather extreme. It nevertheless illustrates a common tendency; that is, for periurbanites, a commune is firstly an object of satisfaction and only secondarily an object of community and identity attachment.

It is in this sociological context that clubbisation takes form. Indeed, with this term, we emphasize how certain communes have exited the political sphere and entered the sphere of the market. ${ }^{21}$ Until a few decades ago, it made no real sense to describe a commune as a club (at least from a sociological perspective) because it meant applying an economic vocabulary to something that was a political rather than economic matter. And, as pluralist philosophers like Michael Walzer demonstrated, the political sphere is linked to principles of justice that are different from those attached to the economic sphere (Walzer, 1983; Miller \& Walzer, 1995). The political power, and more particularly, the power to decide the future of a local society does not obtain its legitimacy from the same sources as economic power. This point is particularly clear in Michael Walzer's discussion on the private city built by Georges Pullman, inventor of the Pullman sleeping cars, in late nineteenth-century Illinois (Walzer, 1983: chapter 12). From an economic standpoint, Pullman could easily expel workers that he had accommodated from his city as soon as they no longer worked for him. From a political standpoint, these workers had the right to decide on the future of their community and of their future in this community, especially if they were long-term residents. In that case, according to Michael Walzer, the prevalence of economic rights over political rights was tantamount to tyranny. This philosophical critique was however founded on the hypothesis of a strong existential connection to the place of residence, established over a long time period. Acknowledging the existence of a culture of mobility makes this hypothesis less pertinent because it weakens the political relationship to places of residence in favour of a more hedonist relationship, based on an evaluation of costs and advantages (under revenue constraint). In such a way, it becomes appropriate to use the concept of club in its economic sense to describe the life world of periurbanites.

\footnotetext{
${ }^{21}$ The distinction made here originates in the pluralist philosophy of Michael Walzer (1983). It is different from the distinction between the economic and the political systems proposed by Jürgen Habermas.Using Habermas vocabulary, our distinction is internal to the "life world".
} 


\subsection{Forms of Residential Clubbisation}

In modern societies, the effects of mobilities are not felt everywhere the same way. The culture of mobility surely provides an environment conducive to the formation of residential clubs, but these clubs establish themselves in many different ways. The political context, the stage of the real estate market, and municipal regulations are obviously determining factors. Common interest developments are the most known forms of clubbisation (McKenzie, 2005). The residential club-like characteristic of these operations is particularly clear in the case of lifestyle communities, such as retirement communities or golf communities. Furthermore, the fact that many of those housing estates are gated communities shows that the question of exclusive access is central (Le Goix \& Webster, 2008).

The emphasis placed on these forms of residential territorialisation leads the academic community to focus its attention on private clubs and therefore on the idea of privatization (Glazse, Webster \& Frantz, 2005; Low \& Smith, 2006). Yet, this article demonstrates that the theme of privatisation does not fully account for the changes in issues and modalities of residential territorialisation in the suburbs. In fact, in France, residential clubs develop from communes, in particular in periurbs.

Admittedly, the process does not concern all communes. In communes that have recently been hit with periurbanisation (type I), the relationship to the local environment continues to belong to a political rather than economic register. These communes may be considered clubs in the economic sense (it is difficult to be elected to City Council if one is not well known in the community), but, sociologically, they are still on the edge of clubbisation. In these communes, mayors are very often farmers and have strong local roots. Many members of the municipal council feel community spirit and they frequently maintain strong social bonds inside the commune. Day-to-day life (particularly the life of farmers, which set the tone) is largely centred on the commune.

However, the arrival of new inhabitants is bringing a change in type I communes. Rural elected representatives often welcome this influx of periurbanites. It is a way to revitalize a local life that had until now suffered from the rural exodus. It allows, for example, for classes to be reopened, indeed even sometimes for a communal school to reopen. Also, the increase in demand for real estate results in a higher appreciation for those owning land. Newcomers have, however, a different point of view. For them, the demographic growth feels more like a curse than a blessing. They therefore often fight urban expansion projects because they consider these to threaten their environment. Indeed, they came to these communes to find peace and verdure and to distance themselves from more urbanized zones. The clash of interests between the "old" residents and the "new" ones that results often incites newcomers to stand for municipal election in order to take control of local politics. Once these newcomers obtain a majority of the votes, the commune is well on its way to becoming a type III.

This observation complements the comments made in the preceding sub-section. It confirms that the clubbisation of a commune is associated to its functional specialization. Indeed, from type I to type III, the major change is that the majority of the inhabitants begin to consider their commune as a strictly residential neighbourhood. The fact that these inhabitants are newcomers also weakens the idea that a commune is an inherited environment that must be transmitted as a patrimony. Newcomers tend to consider their residential environment as a consumer good that they have bought and can resell. 


\subsection{Club Goods Providing Communes}

The situation of the present-day type III communes is the result of a double change. A socio-cultural change, which affects the relationship to neighbouring spaces, and a geographical one, that can be characterized as the passage from rural to periurban. As these changes take place, local politics are becoming increasingly closer to the management of a club. There is some resistance to these changes, notably from the old rural inhabitants, and more generally from people who want their commune to be something else than a "dormitory town". This is why not all communes "clubbise" themselves with the same intensity. Some even voluntarily move towards type II. However, signs of clubbisation are visible to some degree in most periurban communes. This visibility is the highest in type III communes, where the policies in place aim principally at (1) maintaining the population at a constant level or at a slow growth and (2) preserving the qualities of the social environment.

(1) One of the key components of the Tiebout model is a local community's control of its demography. This control is also a key characteristic of clubs as they were defined by James Buchanan: "The central question in a theory of clubs is that of determining the membership margin, so to speak, the size of the most desirable cost and consumption sharing arrangement" (Buchanan, 1965: 2).

The question identified as central by James Buchanan is indeed central for periurbanites. The principal force that can lead them to accept a (moderate) demographic growth may be their desire to have enough children to avoid having to close the communal school. At the same time, periurbanites wish to avoid too strong a growth, as they consider that it would destroy one of the principal qualities that they were looking for when they moved to their commune: the abundance of natural or agricultural areas within proximity of their place of residence.

Indeed, many periurbanites suffer from what may be called "the last arrived syndrome". The proceedings at an information meeting held in a periurban commune near Lyon during which newcomers became angered by a real estate project provides an illustration of this syndrome: "we both work in Lyon, we accept to make a 50 kilometre round-trip to live here. We wanted to live in the country. If you urbanise the area, what will be the benefit to us? We might as well go back to live in the city". This type of discourse is typical of those that say "now that I am here, I want to be the last to arrive".

This explains why, in type III communes, one of the principal goals of the mayors and city councillors is to drastically limit urban expansion. To implement such policies, the communes have all the necessary means. Their control on land use allows them to protect and even expand natural or agricultural areas.

(2) The other important mission assigned by citizens to their city councils is to preserve (even increase) the value of the social environment. The most sought after club good at the local scale, or more precisely the one that most strongly differentiates communes on the residential market, is not a local 
collective good such as a park, a gymnasium or a swimming pool, but the commune's social environment22.

Benefiting from other members' personal characteristics is a common motivation for creating a club (Sandler \& Tschirhart, 1997; Webster, 2003). Yet a commune cannot select members the way, for example, a gentlemen's club does (it is legally forbidden to discriminate among prospective buyers). Nonetheless, social environment is a good that can be provided and managed by a commune for the benefit of its inhabitants. It can be done in several different ways through land use and urban planning. For example, affluent communes can create by-laws prohibiting the construction of houses on small plots. More widespread tools are the rationing of land offer and the refusal of public housing (Demouveaux, 2004). ${ }^{23}$ In regard to this last point, periurban communes have a great leeway for action, since, unlike communes in city centres and in the inner suburbs, they are not subject to the $20 \%$ quota required by the "Solidarite et renouvellement urbain" Act of 2000. Incidentally, this is very appealing for those wishing to move in to a single-family detached dwelling in the periurbs.

This social exclusiveness is the most apparent in the relationship with educational institutions (local, secondary and high schools). On this front, the establishment of student distribution zones between institutions (what is called the "school map" or carte scolaire in France) is a key tool. These zones are in fact relatively impervious and their limits are difficult to overcome ${ }^{24}$. At the national level, the political object of these boundaries is to ensure a certain social mix of those attending educational institutions. However, in periurban areas, it clearly tends to accentuate the segregation of educational institutions. Indeed, most periurban communes serve as basic links in the establishment of recruitment areas for educational institutions. And many Mayors make significant efforts to attach their commune to a good institution, knowing full-well that, in the mind of parents of students, a good institution is generally guaranteed by a good attendance (Charmes, 2007a).

These exclusionary policies are in fact complemented by policies that aim to limit the expansion of the commune's built-up area. Indeed, limiting the size of the population and restricting the possibility of urbanization often result in a rise in real estate values (as the city spreads, the commune gets closer relatively speaking to the centre and attracts more affluent households).

\footnotetext{
22 This observation converges with several studies on the residential real estate market of greater Paris, notably the studies undertaken by Benoît Filippi's team (Filippi et alii, 2007). This observation is also reflected in geographical studies of the socio-spatial division of periurbs (Chenu \& Tabard, 1993 ; Baccaïni, 1998 ; Préteceille, 2003 ; Berger, 2006).

${ }^{23}$ This policy can be related to what is called "exclusionary zoning" or "exclusionary land-use regulations" in Anglo-Saxons countries (Ghorra-Gobin, 1992; Ihlandfeldt, 2004). In France, the reality and the vigour of such policies are highlighted by the debates surrounding social mix or mixité sociale (Esprit, 2004: 121-142).

24 This impermeability has been reduced since 2008 however.
} 
The desire to limit growth in their neighbourhood is not, of course, limited to periurbanites, it is also largely desired in urban centres. The difference, however, is that in urban centres only a very small fraction of the electorate object to real estate projects. In a city of 100,000 inhabitants, 100 dissenters do not carry a substantial weight. In the periurban areas, the situation is very different: One hundred dissenters frequently represent a significant percentage of electors. There are also good chances that several of them may be on familiar terms with the mayor. Furthermore, the attributes of a commune of 100,000 inhabitants have small chances of being modified by the addition of a new residential development welcoming a hundred or so inhabitants. This is not the case for a commune of 1,000 inhabitants.

Based on our research, a threshold can be identified around 2,000 inhabitants for the core built-up area of the commune (the exact number is difficult to determine because population is not the only determining factor and its impact can be adjusted by many other factors). ${ }^{25}$ Around this threshold, a commune distances itself from type III (that is, the "residential commune" category) and moves closer to type II (that is, "small point of services" category). Interestingly, this threshold corresponds with what many other statistical offices (including the French one) have set as being the point at which a built-up unit is urban and no longer rural.

This threshold of 2,000 inhabitants means that one hundred new residents in a commune of a thousand inhabitants significantly move the commune towards another category. Such change jeopardizes the reason why its inhabitants chose to move in. The commune moves closer to the limit between type III and type II, and to the exit of the residential club category. Of course, like all communes, a type II commune can be described as a club, at least from an economic standpoint (Webster \& Lai, 2003). But, firstly, a type II commune is not a residential club. In fact, becoming a small point of services and facilities implies a new relationship with the surrounding area: to sustain its businesses and facilities, the commune has to be open to its surroundings instead of being closed to them. The commune moves from a practice of "residentiality" to a practice of centrality. Secondly, in a type II commune, the connection between the inhabitants and the commune is clearly less consumerist and remains more political than in a type III commune. Residential clubbisation is less obvious. To understand this, it is useful to consider Tiebout's model once again. Indeed, a key idea of the model is that the commune has a "fixed revenue and expenditure pattern". However, as much as this idea makes sense in a type III commune, it is problematic for a type II commune. As a resident of a detached houses estate once told us, "the best remedy for my commune is to do nothing". Such request fits well within a "fixed revenue and expenditure pattern". The problem is that if such expectations can determine local politics in a type III commune, it is not the case in a type II commune. In these communes, the inhabitants of detached house estates may well have similar expectations as their counterparts of type III communes, but their municipal councils may not be in the same position to meet these expectations. These councils are also confronted with the demands of the old centre's inhabitants that are in sufficient numbers to have a

\footnotetext{
${ }^{25}$ Among the factors influencing clubbisation are: the history of the commune, the personality of its mayor, the type of agricultural activities, the distribution of land ownership, and so on (see Charmes, 2006).
} 
strong political influence. The decisions of a municipal council may thus be the result of a political debate, and may not be based on a de facto agreement established at the time of moving (like the contract signed by buyers when they move in to a common interest development).

This observation comes back to a seldom discussed comment that Charles Tiebout made. In the final section of his paper, he briefly considers the normative issue of whether local governments should have a policy complying with his model. He then recognized that: "In a large, dynamic metropolis this may be impossible. Perhaps it could more appropriately be considered by rural and suburban communities" (1956: 423-424). Our observations shed light on this remark, but with a much more restrictive value than Charles Tiebout gave it. He certainly did not believe that the limit could be at around 2,000 inhabitants since he cites as an example a community with 13,000 population (1956: 419).

\section{Conclusion}

The studies which give ground to this article deal with particular circumstances, and interpretations should be made with care. Nevertheless, case studies such as these help to shed light on underlying mechanisms and give opportunities for further in-depth examination. This article brings to the fore the mechanisms of the socio-political transformations that are in progress in French periurban communes. We have shown that the economic concept of club has become pertinent to understand, on one hand, the relationship that periurbanites have with their commune, and, on the other hand, the policies put in place by these same communes.

We have therefore shown that the growing demand for club like management of residential environments can be satisfied by local public governments. This observation is important because the current debate is usually framed within an opposition between private structures and public structures of local government, and within the theme of private structures prevailing over public ones (to lament or to rejoice of it like Robert Nelson, 2005). Within such framework, maintaining public government can be seen as a sign of resistance to the change driven by privatisation. It may then be overlooked that the policies and operating procedures of local governments and councils are also changing, and may themselves becoming reconciled with the principles of justice reigning in the economic sphere. In fact, to achieve control of a residential environment through a club, municipalities are very attractive alternatives as they give the opportunity to take control of sizeable pieces of lands without buying them. ${ }^{26}$ Admittedly, the French periurbs are a particular case, but it seems that similar observations could be made in the United States, at least in places whose local governments are highly fragmented (Lang \&

\footnotetext{
${ }^{26}$ It also seems that municipalities were considered as very attractive alternative in the United States, until many States have taken measure to prevent the incorporation of overly small municipalities. Incidentally, the expansion of homeowner associations in the United-States dates from the 1960's, when such restrictions were implemented. As John Teaford explains: "Homeowner associations increasingly offered the defences desired by suburbanites and reduced the necessity for incorporation. Miniature private governments where thus filling the role played by public governments" (1997: 97-98).
} 
LeFurgy, 2007)..27 Moreover, a general conclusion still can be drawn from our study: the most striking change is less the extension of the private sector than the transformation of the socio-political types of territorialisation. The former should be considered as a symptom of the latter, and not as a cause, contrary to what is often the case in the "privatization" debate (Low \& Smith, 2006).

Another conclusion of our research is that residential clubbisation concerns mostly communes of under 2,000 inhabitants. Further studies are required on the origins of this threshold, and on the factors that may lower or raise it. In particular, it would be useful to improve our understanding of type II communes in order to better understand what distinguishes them from type III communes. But if the level of this threshold can be confirmed, it will have great significance as it may lead to a revision of the terms of the debate around the theme of "private cities" and, more precisely, around the idea that cities submit to the economic order at the detriment of the political order (Low \& Smith, 2006). Indeed, the French example suggests that this tendency mostly concerns residential neighbourhoods, and that, in communes with populations of at least several thousands, the political sphere remains determining in the inhabitants' relationship to their commune. Again, the French periurbs are a particular case. It remains to be seen, therefore, whether a similar threshold can be identified for homeowners' associations and common interest developments. Considering the literature on the latters, one can hypothesize that public government lowers the population threshold between the economical and the political spheres. In other words, private governments may be more "resistant" to the political sphere than public government. This is an important research avenue opened up by this article.

Our results open up other research avenues. Undeniably, the sociological and political evolutions described in this article are not particular to France or to periurbs. Founded on the emergence of a culture of mobility and on the consumerisation of the relationship to the residential environment, the demand for clubbisation can be found in many contexts. It is the way that this demand becomes institutionalised that is variable. In some cases, it takes the form of homeowners' associations and common interest developments (Webster, 2002; McKenzie, 2005). In other cases, it takes the form of residents' associations and nimbyist groups (Dear, 1993; Keil \& Ronneberger, 1994; Fischel, 2001). In the French periurbs, residential clubbisation emerges from small communes. Many questions ensue from this observation: what determines that at a certain moment, in a certain place, clubbisation takes one form instead of another? From the periurbanites viewpoint, what are the advantages and disadvantages of a small municipality? How and why will they prefer to move into a private residential development? Chris Webster has provided some answers using transaction costs, property rights and related ideas from the new institutional economics (2003). But, as we have just seen, a socio-political perspective can be useful as well.

It would also be of use to study the political and social impacts of the different forms of residential clubbisation. The most important questions would concern the effects of the social division of space. Indeed, the transformation of periurbanites into consumers of local public goods usually leads them to sort themselves according to their preferences and incomes (Hamilton, 1975). This normally leads to the partitioning of local governments into socially homogeneous areas (Dowding \& John, 1994). Socio-

\footnotetext{
${ }^{27}$ According to Robert Lang and Jennifer LeFurgy, many of the small municipalities that now exist in the American suburbs are close to being "private clubs". They suggest to use the label "cluburbs" for those municipalities, and they compare them to gated communities with invisible walls (2007: 127-128).
} 
spatial homogenisation is indeed currently happening at the municipal level in the French periurbs (Berger, 2006). This homogenisation raises the issue of daily confrontation to otherness and the issue of the social solidarity that is supposed to result from it. Does solidarity make sense if it remains an abstract and non-concrete commitment? Do we not risk observing a recoil of this solidarity in the long run, with the daily invisibility of "others" progressively leading to their political invisibility (Lagrange, 2006; Low, 2003)? At the same time, until what point should we mourn the loss of public space in residential neighbourhoods, since daily mobilities displace confrontation to otherness out of the place of residence (Charmes, 2007b).

Anyway, the social division of space may also be correlated to inequalities with regard to access to services and local equipment. Available surveys indicate that residential choices are above all determined by financial capacities (Filippi et alii, 2007). If one believes that access to certain collective goods should not be based on revenue, then residential clubs that are established this way pose a problem. A recurrent criticism made about those who take normative consequences for urban governance from Tiebout's model (e.g. advocates of local government fragmentation ${ }^{28}$ ) is indeed that the model assumes access to local services such as education, security and sanitation is greatly socially differentiated. In fact, in this matter, there are less varied preferences that must be satisfied than there are similar needs that are unequally satisfied because of varied resources (Kelleher \& Lowery, 2002; Estèbe, 2008). Furthermore, unequal access to these services cannot be considered benign to a society, especially when it concerns access to education. These are difficult questions that are beyond the scope of this study. We will simply note that clubbisation is based on significant transformations that would be difficult to reverse. Therefore, research should focus on the redistribution mechanisms between residential clubs and on how households that increasingly behave as "consumer-voters" may contribute to social solidarity.

\section{References}

BACCAIINI B. (1998) Recent periurban growth in the lle-de-France: forms and causes, Population: An English Selection. vol. 10, $n^{\circ}$ 2, pp. 349-384

BERGER M. (2006) Périurbanisation et accentuation des logiques ségrégatives en lle-de-France, Hérodote. $n^{\circ} 122,3^{e}$ trimestre, p. 198-211

BERGER M. (2005) Les périurbains de Paris. De la ville dense à la métropole éclatée. Paris: Presses du CNRS

BERUBE A. et alii (2006) Finding Exurbia: America's Fast-Growing Communities at the Metropolitan Fringe, Living Cities Census Series. October, The Brookings Institution

BIDOU C. (1984) Les Aventuriers du quotidien. Essai sur les nouvelles classes moyennes. Paris: Presses universitaires de France

${ }^{28}$ For Charles Tiebout's point of view on that matter see (Ostrom, Tiebout \& Warren, 1961). 
BREVARD L. (2003) Les trajectoires d'insertion des nouveaux habitants à la périphérie des villes. Phd dissertation under the direction of Jaillet M-C., University of Toulouse Le Mirail

BUCHANAN J-M. (1965) An Economic Theory of Clubs, Economica. New Series, vol. 32, n 125 , February, p. 1-14

CHARMES E. (2005) La vie périurbaine face à la menace des gated communities. Paris: L'Harmattan

CHARMES E. (2006) Les petites communes périurbaines face aux nouvelles formes de l'entre-soi. Research report. Paris: PUCA

CHARMES E. (2007a) Carte scolaire et clubbisation des petites communes périurbaines, Sociétés contemporaines. $n^{\circ} 67$, p. 67-94

CHARMES E. (2007b) Suburban fragmentation versus mobilities. Is suburbanism opposed to urbanism?, Cybergeo. $\mathrm{n}^{\circ} 369$

CHAUVEL L. (2006) Les classes moyennes à la dérive. Paris: Seuil

CHENU A. \& TABARD N. (1993) Les transformations socioprofessionnelles du territoire français, 1982 1990, Population. vol. 48, n 6, nov-dec, p. 1735-1769

COASE R.H. (1974) The lighthouse in economics, Journal of Law and Economics. vol. 17, $n^{\circ} 2$, October, p. 357-376

DEAR M. (1993) Comprendre et surmonter le syndrome NIMBY, 2001 Plus. $n^{\circ}$ 27, p. 2-20

DEMOUVEAUX J-P. (2004) Le droit de l'urbanisme au service de la ségrégation urbaine, in ADEF, Les mécanismes fonciers de la ségrégation. Paris: ADEF, p. 113-137

DOWDING K. \& JOHN P. (1994) Tiebout: A survey of the empirical literature, Urban Studies. vol. 31, $n^{\circ} 4 / 5$, p. $767-798$

ESPRIT (2004) Table ronde La Mixité urbaine est-elle une politique ?. n 303, mars-avril, p. 121-142

ESTÈBE P. (2008) Gouverner la ville mobile. Paris: Presses universitaires de France

FILIPPI B. et alii (2007) Marchés du logement et fractures urbaines. Lyon: CERTU, collection

« recherches » du PUCA

FISCHEL W. A. (2001) Why Are There NIMBYs, Land Economics. vol. 77, n 1, p. 144-152

FOLDVARY F. (1994) Public Goods and Private Communities. The Private Provision of Social Services. Cheltenham: Edward Elgar

GLASZE G., WEBSTER C. \& FRANTZ (Ed.) (2005) Private Cities: Global and Local Perspectives. London: Routledge

GHORRA-GOBIN C. (1992) Planification urbaine et incorporation aux Etats-Unis. Les fondements de la politique d'exclusion, Les Annales de la recherche urbaine. $n^{\circ}$ 51, p. 40-47

GUENGANT A. (1992) Les coûts de la croissance périurbaine. L'exemple de l'agglomération rennaise. Paris: ADEF

HAMILTON B.W. (1975) Zoning and property taxation in a system of local government, Urban Studies. vol. $12, n^{\circ} 2$, p. $205-211$ 
IHLANDFELDT K.R. (2004) Exclusionary land-use regulations within suburban communities: a review of the evidence and policy prescriptions, Urban Studies, vol. 41, n² 2, p. 261-283

JAGLIN S. (dir.) (2008) Territorialisation des espaces urbanisés dans les grandes villes : une confrontation nord/sud. Paris : LATTS, CNRS

JAILLET M-C. (2004) L'Espace périurbain : un univers pour les classes moyennes, Esprit. n 303. marsavril, p. 40-61

JUDD D.R. \& SWANSTROM T. (2004) City Politics. Private Power and Public Policy. New York:

Pearson Longman

KEIL R. \& RONNEBERGER K. (1994) Going up the country: Internationalization and urbanization on Frankfurt's northern fringe, Environment and Planning D: Society and Space. $n^{\circ} 12$, p. 137-166

KELLEHER C. \& LOWERY D. (2002) Tiebout sorting and selective satisfaction with urban public services. Testing the variance hypothesis, Urban Affairs Review. vol. 37, n 3, p. 420-431

LAGRANGE H. (Ed.) (2006) L'épreuve des inégalités. Paris: Presses universitaires de France

LANG R.E. \& LEFURGY J.B. (2007) Boomburbs: The Rise of America's Accidental Cities. Brookings Institution Press.

LEFEVRE C. (2001) L'évolution de l'organisation institutionnelle des Etats européens. Des processus de décentralisation marqués par le poids des héritages nationaux. Paris: IAURIF

LE GOIX R. \& WEBSTER C. (2008) Gated communities, Geography Compass. Vol. 2, n 4, p 11891214

LOW S.M. (2003) Behind the Gates. Life, Security and the Pursuit of Happiness in Fortress America. Routledge

LOW S \& SMITH N. (Ed.) (2006) The Politics of Public Space. Routledge

MCKENZIE E. (2005) Planning through residential clubs: homeowners' associations, Economic Affairs. vol. $25, n^{\circ} 4$, p. $28-31$

MILLER D. \& WALZER M. (1995) Pluralism, Justice and Equality. Oxford University Press

NELSON R.H. (2005) Private Neighborhoods and the Transformation of Local Government. Urban Institute Press

OATES W.E. (1969) The effects of property taxes and local public spending on property values: An empirical study of tax capitalization and the Tiebout hypothesis, Journal of Political Economy. vol. 77, november, p. 957-971

OSTROM E., GARDNER R. \& WALKER J. (1993) Rules, games, and common-pool resources. Ann Arbor: The University of Michigan press

OSTROM V., TIEBOUT C.M. \& WARREN R. (1961) The organization of government in Metropolitan areas: A theoretical inquiry, The American Political Science Review. vol. 55, n 4, p. 831-842 PHILLIPS T. \& SMITH P. (2006) Rethinking urban incivility research: Strangers, bodies and circulation, Urban Studies, vol. 43, n 5/6, p. 879-901 
PINSON D. \& THOMANN S. (2002) La maison en ses territoires. De la villa à la ville diffuse. Paris: L'Harmattan

PRETECEILLE E. (2003) La division sociale de l'espace francilien. Typologie socioprofessionnelle 1999 et transformations de l'espace résidentiel 1990-99. Paris: research report, observatoire sociologique du changement

PRÉTECEILLE E. (2006) La ségrégation contre la cohésion sociale. La métropole parisienne, in Lagrange H. (dir.), L'épreuve des inégalités. Paris: PUF, p. 195-246

PUTNAM R. (2000) Bowling Alone. The Collapse and Revival of American Community. New York: Touchstone

RAMADIER T. (2002) Rapport au quartier, représentation de l'espace et mobilité quotidienne. Le cas d'un quartier périphérique de Québec-Ville, Espaces et Sociétés, n 108-109, p. 111-131

REMY J. (2004) Culture de la mobilité et nouvelles formes de territorialité, in Vodoz L, Pfister-Giauque B. \& Jemelin C. (dir.), Les territoires de la mobilité. L'aire du temps. Lausanne: Presses polytechniques et universitaires romandes, p. 13-42

RHODE P.W. \& STRUMPF K.S. (2003) Assessing the importance of Tiebout Sorting: Local heterogeneity from 1850 to 1990, The American Economic Review. vol. 93, n 5, December, p. 16481677

ROUGÉ L. (2005) Accession à la propriété et modes de vie en maison individuelle des familles modestes installées en périurbain lointain. Les " captifs " du périurbain ? PhD dissertion under the direction of Jaillet M-C. Toulouse: University of Toulouse-Le Mirail

SACK R. (1986) Human Territoriality. Its Theory and History. Cambridge: Cambridge University Press

SANDLER T. \& TSCHIRHART (1997) Club theory: Thirty years later, Public Choice, n 93, p. 335-355

SOJA E. (2000) Postmetropolis. Critical Studies of Cities and Region. Blackwell Publishing

TEAFORD J.C. (1997) Post-Suburbia. Government and Politics in the Edge Cities. Baltimore and London: The John Hopkins University Press

TIEBOUT C. (1956) A Pure Theory of Local Expenditures, The Journal of Political Economy. vol. 64, $n^{\circ}$ 5, October, p. 416-424

URRY J. (2000) Sociology beyond Societies. Mobilities for the Twenty-First Century. London: Routledge VILMIN T. (2006) Le Système local de l'urbanisation en maisons individuelles. Etude de cas en lle-deFrance. Logiville, rapport pour le PUCA, ministère de l'Equipement

WALZER M. (1984) Spheres of Justice. A Defense of Pluralism and Equality. New York: Basic Books WEBSTER C.J. (2002) Property rights and the public realm. Gates, green belts and gemeinschaft, Environment and Planning B. vol. 29, n 3, p. 397-412

WEBSTER C.J (2003) The nature of the neighbourhood, Urban Studies. vol. 40, n¹3, p. 2591-2612 WEBSTER C.J. \& LAI L.W.C. (2003) Property Rights, Planning and Markets. Managing Spontaneous Cities. Cheltenham, Northampton: Edward Elgar 
WOLLMANN H. (2000) Local government systems: from historic divergence towards convergence? Great-Britain, France, and Germany as comparative cases in point, Environment and Planning C: Government and Policy. Vol. 18, p. 33-55 